\title{
Discovery of an Eo-Meso-Neoarchean terrane in the East Greenland Caledonides
}

\author{
Scott M. Johnston ${ }^{\mathrm{a}, *}$, Andrew R.C. Kylander-Clark ${ }^{\mathrm{b}}$ \\ a Physics Department, California Polytechnic State University, San Luis Obispo, CA 93407, United States \\ ${ }^{\mathrm{b}}$ Department of Earth Science, University of California, Webb Hall, BLDG 526, Santa Barbara, CA 93106, United States
}

\begin{abstract}
A B S T R A C T
This study investigates basement gneisses from the Niggli Spids thrust sheet of the East Greenland Caledonides in an attempt to place them into the broader context of the Archean-Paleoproterozoic architecture of the Greenland shield. Our combined whole-rock geochemical and U-Pb zircon geochronology results from Gåseland reveal an Archean terrane defined by TTG magmatic events at $3607 \mathrm{Ma}$ and 3070-2980 Ma followed by metamorphism and high-K granite intrusion at 2790-2677 Ma. These results identify a relatively pristine Archean terrane with previously unknown Eoarchean rocks that holds potential for future investigations into the early evolution of continental crust, and adds to a growing body of data characterizing the Archean-Paleoproterozoic architecture of East Greenland.
\end{abstract}

\section{Introduction}

Precambrian cratonal fragments and orogenic belts preserve rich histories that record the creation of the Earth's earliest continental crust (e.g., Nutman et al., 1996) as well as the periodic formation and demise of supercontinents (e.g., Hoffman, 1997). Unfortunately, the details of these early Earth global processes are commonly obscured by subsequent deformation suffered during younger tectonic events, and considerable differences between competing models still exist for the evolution of early continental crust and in the configurations of the earliest supercontinents. Archean-Paleoproterozoic rocks have long been recognized within the Phanerozoic East Greenland Caledonides (Hansen et al., 1981; Rex and Gledhill, 1974), although the relationship of these terranes with respect to North Atlantic paleogeography remained poorly understood until more recent regional mapping projects and geochronology studies placed considerable new constraints on the pre-Caledonian architecture of the region (e.g., Higgins et al., 2004 , and references therein). In this contribution, we identify an Eo-Meso-Neoarchean terrane within the Niggli Spids thrust sheet of the East Greenland Caledonides that adds to the database of early Earth rocks > 3.6 Ga, expands the aerial extent of Archean terranes in East Greenland, and highlights the future potential for the

\footnotetext{
* Corresponding author. Tel.: +1 8057561650.

E-mail address: scjohnst@calpoly.edu (S.M. Johnston).
}

Archean-Paleoproterozoic terranes of East Greenland to place new constraints on the configuration of Paleoproterozoic Nuna paleogeography.

\section{Geologic background}

The East Greenland Caledonides consist of a series of thrust sheets or nappes that were transported westward over the Greenland shield (Fig. 1A) during the closure of the Iapetus Ocean and the ultimate collision of Laurentia with Baltica in the Silurian-Devonian Caledonian orogeny (e.g., Leslie and Higgins, 2008). Beneath the Greenland ice sheet, the Greenland shield includes Archean rocks that were thermally reset during the Paleoproterozoic (Weis et al., 1997), whereas the westernmost, and structurally lowest units exposed in the parautochthonous foreland windows of the East Greenland Caledonides consist of Paleoproterozoic gneisses, granites, and sedimentary rocks unconformably overlain by Paleozoic sedimentary rocks (Hansen et al., 1981; Higgins and Leslie, 2004; Thrane, 2004). Although early isotopic studies suggested Archean ages for at least some of the foreland basement gneisses (Hansen et al., 1981), more recent U-Pb zircon geochronology studies have yielded ages of 1930-1915 Ma from basement orthogneisses (Thrane, 2004), and Archean rocks are not known from the parautochthonous foreland windows. Farther east, Archean rocks (Rex and Gledhill, 1974; Steiger et al., 1979; Thrane, 2002)-termed herein the East Greenland Archean domain (EGAD)-are unconformably overlain by Late 


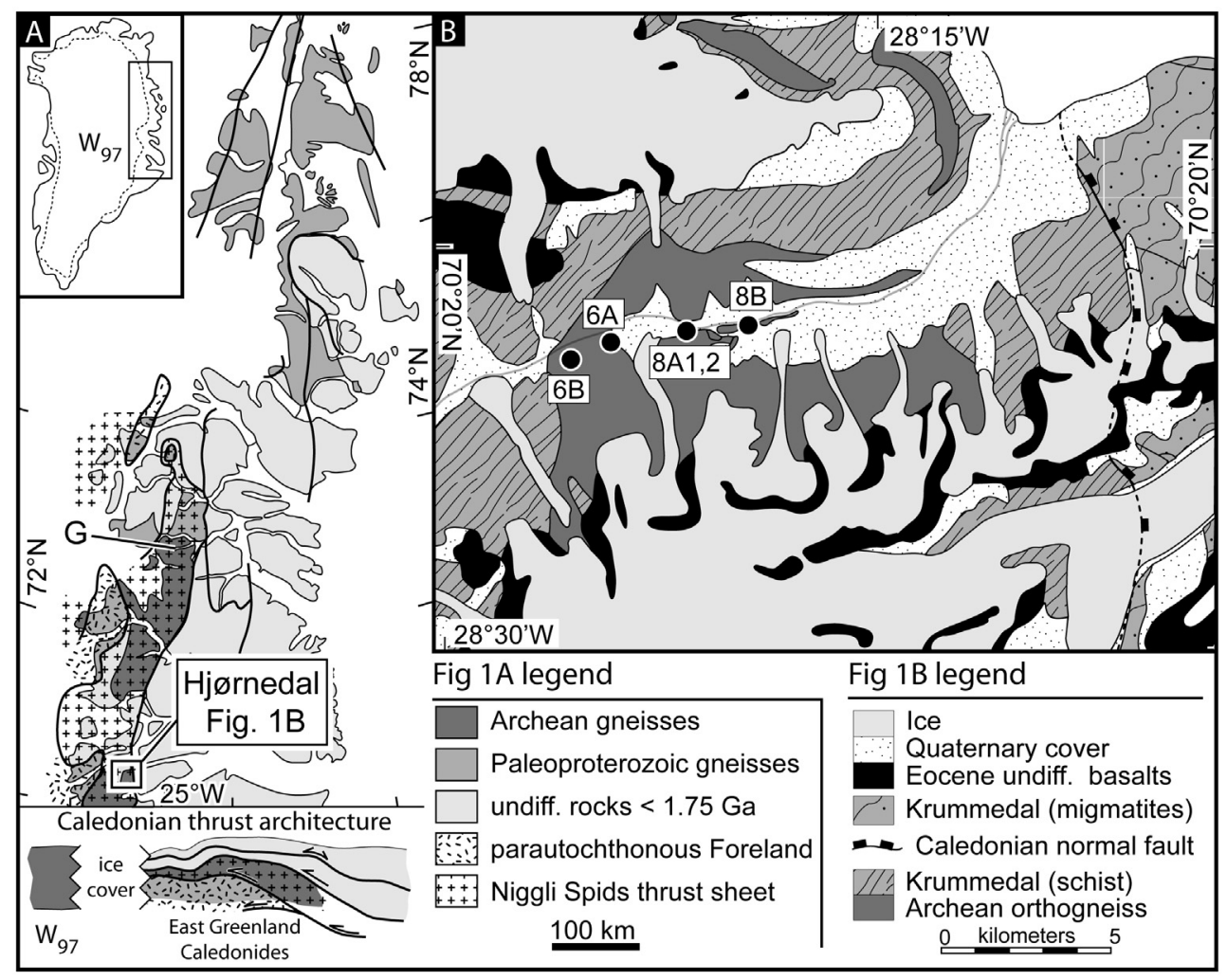

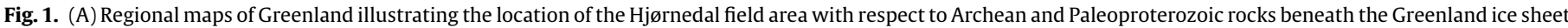

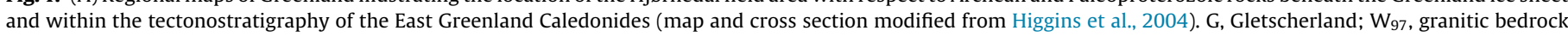

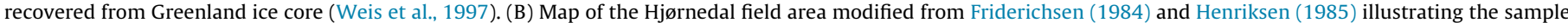
locations within the context of the local geology. Exact coordinates for each sample are listed in Table DR1.

Mesoproterozoic-Early Neoproterozoic sedimentary rocks of the Krummedal sequence and exposed within the Niggli Spids thrust sheet, which was ultimately transported westward and structurally above the Paleoproterozoic foreland during Caledonian deformation (Fig. 1A inset; Higgins et al., 2004). To the north within the Niggli Spids thrust sheet, and in structurally higher/more easterly thrust sheets, these Archean basement gneisses are juxtaposed against more Paleoproterozoic gneisses that are part of a $1000 \mathrm{~km}$-long N-S or NW-SE trending Paleoproterozoic arc and associated post-orogenic magmatic rocks (Gilotti and McClelland, 2011; Kalsbeek et al., 1993b; Thrane, 2002), and may be correlative to Paleoproterozoic volcano-sedimentary rocks in eastern North Greenland (Pedersen et al., 2002). Despite similar magmatic ages, spatially incomplete datasets and subsequent Caledonian deformation have precluded potential correlations between Paleoproterozoic rocks exposed in the Caledonian thrust sheets, in the parautochthonous foreland, and in other North Atlantic Paleoproterozoic orogens.

Farther afield, the Precambrian geology of North Atlantic terranes in Laurentia and Baltica are similarly characterized by Archean cratons joined by Paleoproterozoic orogens (Fig. 2). The Laurentian shield in West Greenland is closely linked to the TransHudson tectonic history of northeastern Laurentia and consists of Paleoarchean rocks exposed in the Arctic, the Meso-Neoarchean Rae craton in central West Greenland, and the Eo-Neoarchean North Atlantic craton in southern West Greenland, and was pieced together from north to south during the Paleoproterozoic by the Inglefield Mobile Belt and the Nagssugtoquidian orogens, respectively (Nutman et al., 2008b; St-Onge et al., 2009). The Nagssugtoquidian orogen and the North Atlantic craton can be traced beneath the ice sheet to the east coast of Greenland (Kalsbeek et al., 1993a; Nutman et al., 2008b), whereas the southernmost tip of Greenland is composed of the juvenile Paleoproterozoic rocks of the Ketilidian orogeny (Garde et al., 2002). Across the Atlantic, numerous paleomagnetic studies have linked northeastern Laurentia to the Baltic shield within the Paleoproterozoic supercontinent Nuna (Buchan et al., 2000; Patchett et al. 1978; Poorter, 1976). The Baltic shield includes the northerly Neoarchean Murmansk and southerly Paleo-Neoarchean Karelian cratons (Slabunov et al., 2006) that were juxtaposed during the Paleoproterozoic Lapland-Kola orogeny (Daly et al., 2006). The Karelian craton is bordered to the south by the Paleoproterozoic Svecofennian juvenile arc complex (Nironen, 1997) and a series of Mesoproterozoic convergent margin accretionary orogens that are similar in age to the accreted terranes of southern Greenland and Laurentia (Karlstrom et al., 2001). The similar Archean-Mesoproterozoic relationships observed in both northeastern Laurentia and Baltica have been used to refine paleomagnetic models describing the orientation of Baltic with respect to Laurentia within Nuna (Bridgwater et al., 1990; Buchan et al., 2000; Gorbatschev and Bogdanova, 1993; Gower et al., 1990; Park, 1994), although these geologically-modified models have traditionally been hampered by a lack of data documenting the Archean-Paleoproterozoic terranes of East Greenland.

\section{Geochronology and geochemistry of Hjørnedal basement gneisses}

To place new constraints on the Archean-Paleoproterozoic evolution of the East Greenland shield, we investigated the basement gneisses of Niggli Spids thrust sheet exposed in Hjørnedal, Gåseland (Fig. 1B). The Niggli Spids thrust sheet in Hjørnedal includes a suite of granitic gneisses and amphibolites overlain by Krummedal sequence sedimentary rocks (Friderichsen, 1984; 


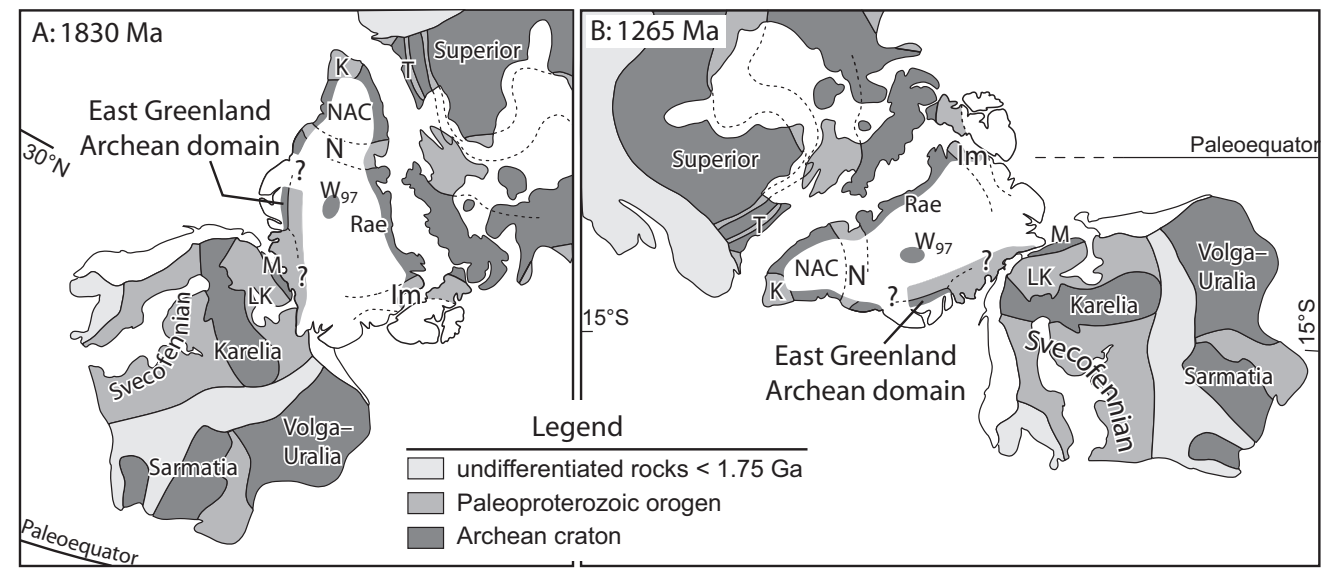

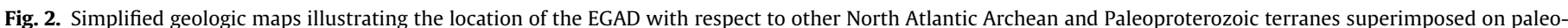

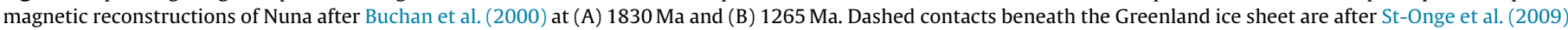

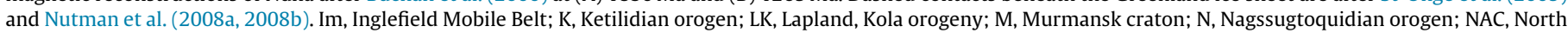
Atlantic craton; T, Torngat orogen; $W_{97}$, granitic bedrock recovered from Greenland ice core (Weis et al., 1997).

Henriksen, 1985); muscovite-kyanite-garnet assemblages developed in pelitic rocks from the Krummedal sequence indicate Caledonian amphibolite-facies metamorphism of the Niggli Spids basement-cover pair (Johnston et al., 2010). We selected four granitoid gneisses and a cross-cutting granitic dike from the basement suite for further whole-rock geochemistry and zircon $\mathrm{U}-\mathrm{Pb}$ geochronology; two samples were also analyzed for zircon and Hf isotopes. Whole-rock geochemistry (Fig. 3) was completed at the Washington State University GeoAnalytical Laboratory and zircon U-Pb geochronology (Fig. 4) and Hf isotopes (Fig. 5) were performed at the University of California, Santa Barbara Dual-ICP Laboratory using laser ablation ICPMS (Kylander-Clark et al., 2013). Reported ages are ${ }^{207} \mathrm{~Pb} /{ }^{206} \mathrm{~Pb}$ weighted averages with errors at the $95 \%$ confidence level from analyses $<5 \%$ discordant, or ${ }^{207} \mathrm{~Pb} /{ }^{206} \mathrm{~Pb}$ age ranges from analyses $<10 \%$ discordant in samples that do not yield single age populations. $\varepsilon_{\mathrm{Hf}}$ values were calculated using CHUR values from Bouvier et al. (2008) and the ${ }^{176}$ Lu decay constant from Scherer et al. (2001) with model ages assigned by the previously determined U-Pb zircon age. Sample locations, geochemical data, zircon $\mathrm{CL}$ images and complete $\mathrm{U}-\mathrm{Th}-\mathrm{Pb}$ and $\mathrm{Hf}$ isotope data are available in the data repository (Fig. DR1-5, Tables DR1-3).

Sample 6B is a granodioritic gneiss with foliation defined by biotite-rich interlayers. This sample has a low Mg\# (39), moderate $\mathrm{K}_{2} \mathrm{O} / \mathrm{Na}_{2} \mathrm{O}(0.64)$, and a trace element profile with a subtle negative Eu anomaly and depleted heavy rare earth elements (HRRE) with respect to average continental crust (Fig. 3). Abundant pink prismatic zircons separated from this sample range in size from $100-250 \mu \mathrm{m}$ in length and show oscillatory zoning in $\mathrm{CL}$. $\mathrm{U}-\mathrm{Pb}$ isotopic analyses form a complex mixing array in concordia space defined by discordia with Eo-Neoarchean upper intercepts and high-U analyses pulled toward a Caledonian lower intercept (Fig. 4A); ten analyses with nearly concordant ${ }^{207} \mathrm{~Pb} /{ }^{206} \mathrm{~Pb}-{ }^{238} \mathrm{U} /{ }^{206} \mathrm{~Pb}$ ages define an upper-intercept age of $3607 \pm 37 \mathrm{Ma}$. This rock is $\mathrm{Zr}$-undersaturated $(176 \mathrm{ppm})$ with respect to typical TTG melts, suggesting that the Eoarchean zircon population is not inherited (Mojzsis and Harrison, 2002; Watson and Harrison, 1983), and that 3607 Ma represents the magmatic age of this granodiorite. Hf isotopic analyses (Fig. 5) consist of two distinct populations, the larger of which yields a
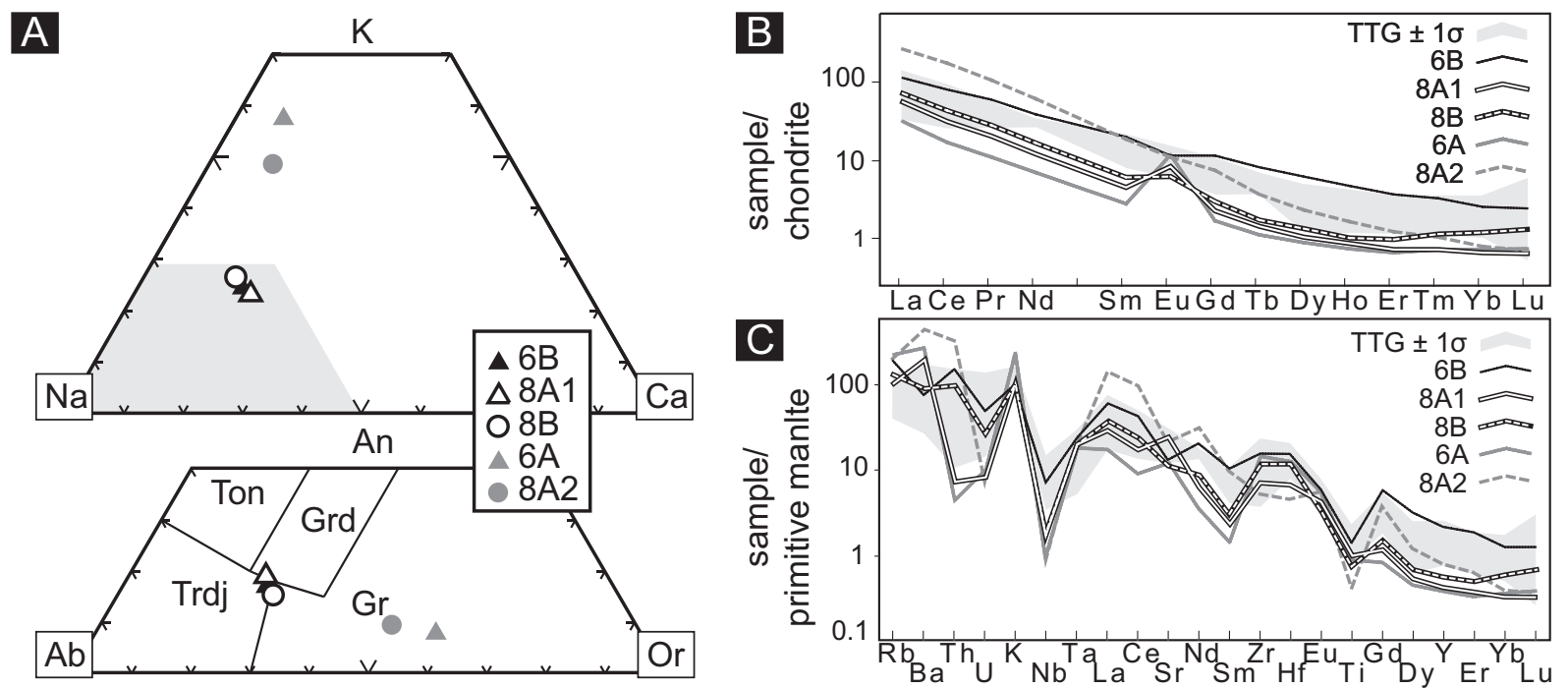

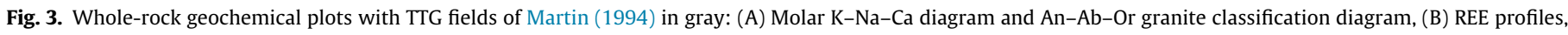
and $(\mathrm{C})$ trace element profiles. 

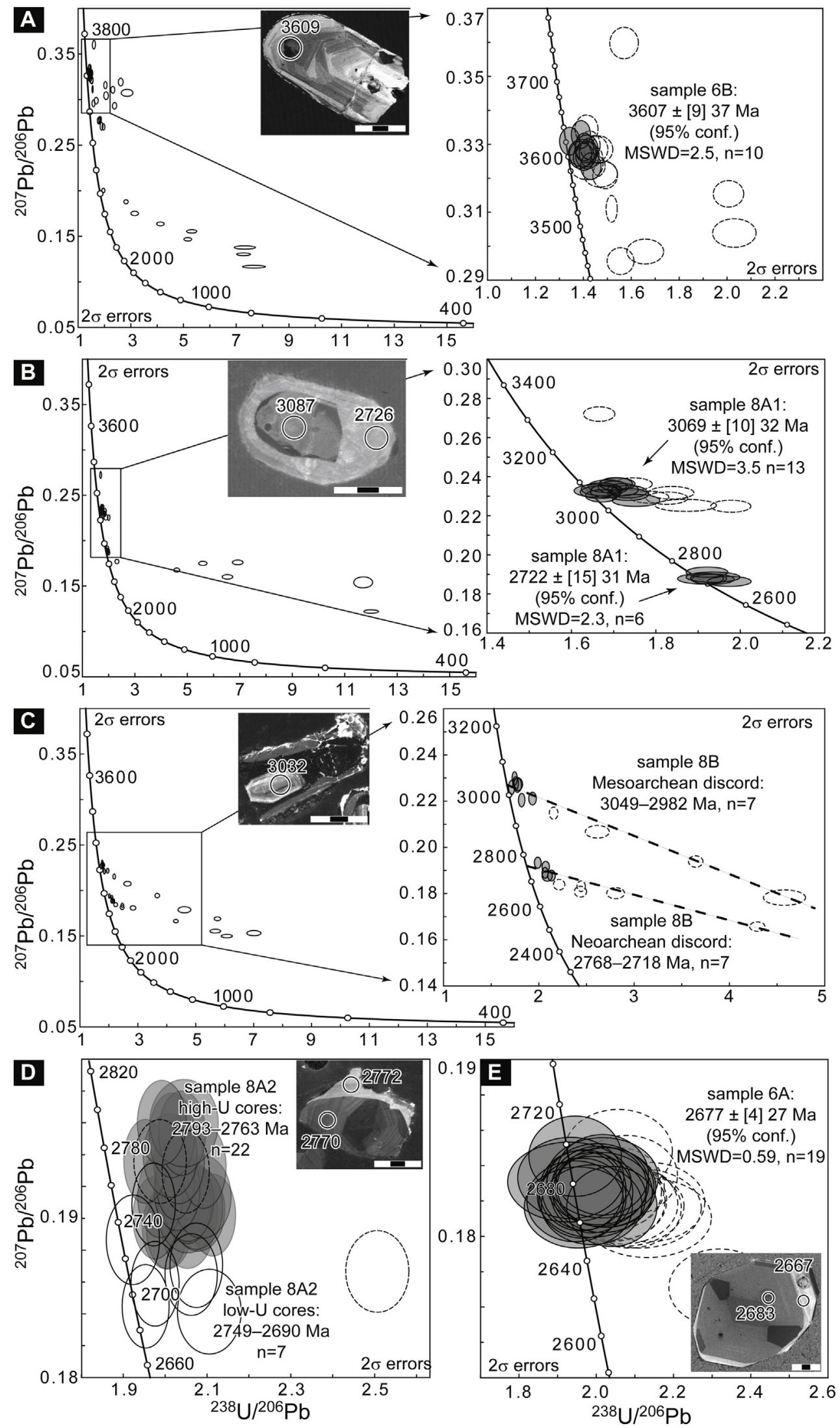

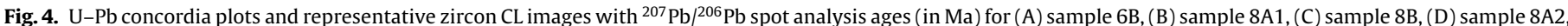

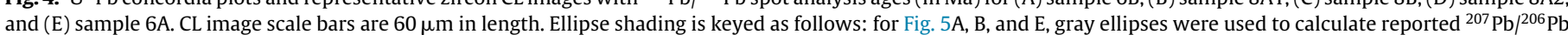

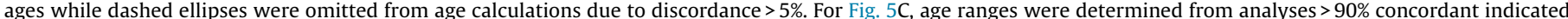

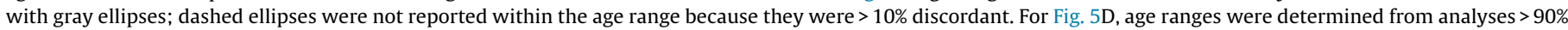

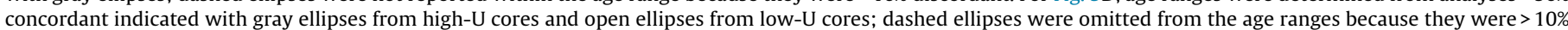
discordant. 

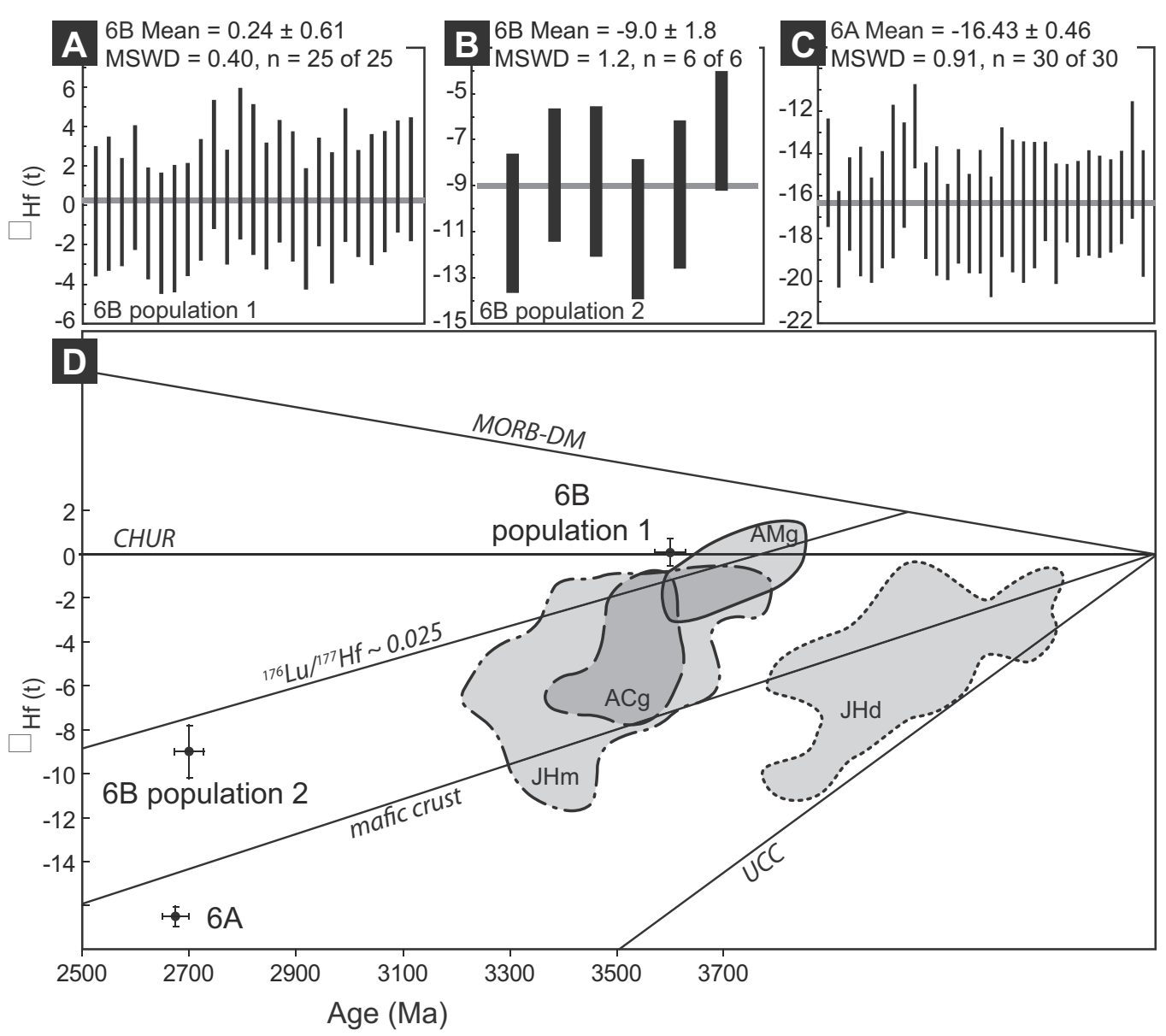

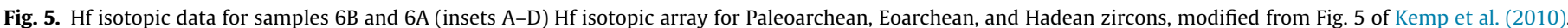

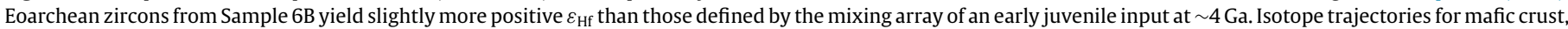

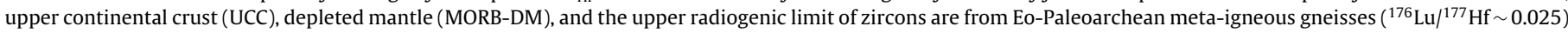

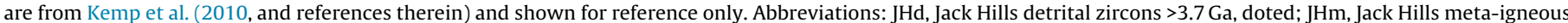
zircons, dash-dot; ACg, Acasta gneiss, long dash; AMg, Amîtsoq gneiss, solid line.

single, initial $\varepsilon_{\mathrm{Hf}}$ value of $0.24 \pm 0.61(\mathrm{MSWD}=0.40)$ at $3607 \mathrm{Ma}$. The second population is interpreted to represent $\mathrm{Hf}$ redistribution during Meso-Neoarchean events, yielding an initial $\varepsilon_{\mathrm{Hf}}$ of $-9.0 \pm 1.8$ $(\mathrm{MSWD}=1.2$ ).

Samples 8A1 and 8B are variably foliated biotite granodiorite gneisses with leucocratic K-feldspar-rich layers and porphyroclasts. These gneisses are characterized by low $\mathrm{Mg \#} \mathrm{(<48),}$ moderate $\mathrm{K}_{2} \mathrm{O} / \mathrm{Na}_{2} \mathrm{O}(\sim 0.65)$, and trace element profiles with strongly depleted HREEs and positive Eu anomalies (Fig. 3). Colorless zircons from 8A1 display oscillatory cores and bright unzoned rims up to $50 \mu \mathrm{m}$ in width in CL. U-Pb analyses from 13 zircon cores yield an age of $3069 \pm 32 \mathrm{Ma}$, whereas a group of $6 \mathrm{rim}$ analyses yield an age of $2722 \pm 31 \mathrm{Ma}$ (Fig. 4B). Zircons from 8B display oscillatory cores, dark mantles and thin, bright rims in CL. High-U zircons (up to $2000 \mathrm{ppm}$ ) from this sample form two discordant arrays with Mesoarchean and Neoarchean upper intercepts pulled toward a Caledonian lower intercept (Fig. 4C). 7 core analyses range from 3049-2982 Ma, and 5 mantle analyses range from 2768-2718 Ma. Bimodal zircon age populations, the core-rim morphology observed in $\mathrm{CL}$, and the low $\mathrm{Zr}$ content of these samples $(<140 \mathrm{ppm})$, suggests these rocks date the timing of Mesoarchean plutonism overprinted by Neoarchean metamorphism.

Sample $6 \mathrm{~A}$ is a coarse granite dike that cuts subvertically across foliated granodioritic gneiss (Fig. 6), and 8A2 is a concordant biotite granite gneiss with $\mathrm{K}$-spar augen up to $3 \mathrm{~cm}$ in diameter. These
K-rich granites have depleted HREEs, although $8 \mathrm{~A} 2$ has enriched LREEs and no Eu anomaly, while 6A is characterized by depleted LREEs and a positive Eu anomaly (Fig. 3). Zircon fragments from

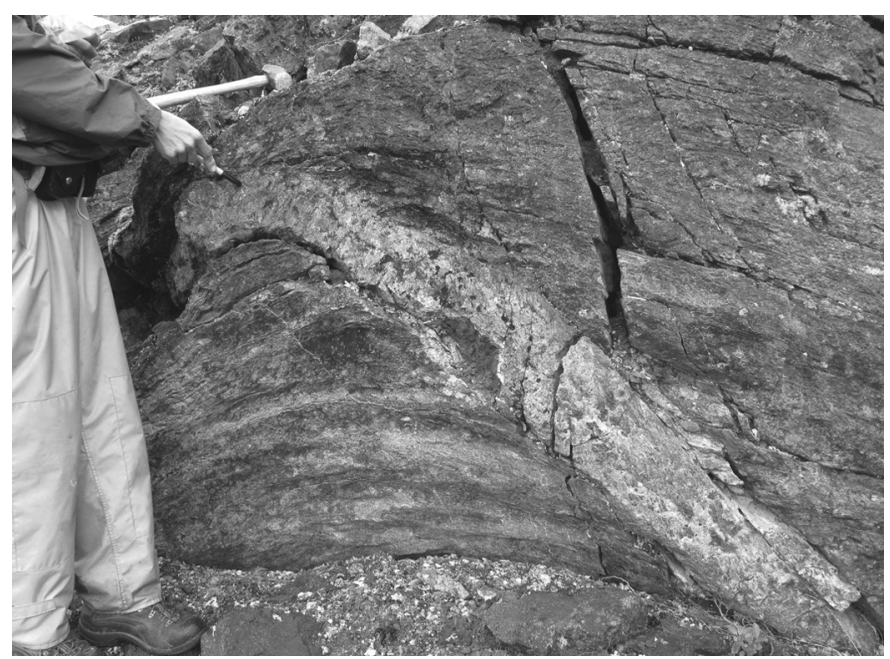

Fig. 6. Field photograph of granitic dike sample $6 \mathrm{~A}$ illustrating its cross cutting relationship with the tonalitic host gneiss. 
sample 8A2 display sector zoned cores and bright, patchy rims. $\mathrm{U}-\mathrm{Pb}$ isotope analyses yield a cluster of slightly discordant analyses ranging from 2793-2736 Ma in high-U cores and 2749-2690 Ma in low-U rims (Fig. 4D). Zircons separated from 6A display sector zoning in CL, and a group of 19 analyses yield an age of $2677 \pm 27 \mathrm{Ma}$ (Fig. 4E) that documents the timing of Neoarchean granitic intrusion. Hf isotopic data yield a single population of initial $\varepsilon_{\mathrm{Hf}}-16.43 \pm 0.46$ (MSWD=0.91; Fig. 5).

\section{Discussion}

\subsection{Identification of previously undiscovered Eoarchean rocks}

These new data significantly expand our understanding of Archean geology of East Greenland north of the Nagssugtoquidian orogen. At the local scale, the Hjørnedal basement gneisses are characteristic of a composite Archean terrane defined by Eoarchean and Mesoarchean TTG magmatism followed by Neoarchean metamorphism and $\mathrm{K}$-rich granite intrusion. $\mathrm{U}-\mathrm{Pb}$ isotope data from zircon does not reveal any evidence for a Paleoproterozoic thermal event, and while many analyses are spread along discordia with Paleozoic lower intercepts, these analyses are strongly correlated with high-U concentrations indicative of Caledonian Pb-loss without significant growth of new zircon. In addition, the highangle cross-cutting relationship displayed between Neoarchean dike $6 \mathrm{~A}$ and older gneiss suggests that despite the presence of Paleoproterozoic orogenic events found in structurally lower nappes and amphibolite-facies Caledonian metamorphism, this region preserves original Archean intrusive and metamorphic relationships. The size and petrologic variability of the Hjørnedal Eoarchean rocks have yet to be fully characterized, and without a larger sample size, our reconnaissance dataset should not be overinterpreted with respect to early Earth processes. Still, these results are broadly consistent with recent detrital zircon studies that yield evidence for Eoarchean crust extraction and Paleoarchean zircon growth in East Greenland source terranes (Slama et al., 2011). Furthermore, the similarities of the Hjørnedal rocks with other Eoarchean terranes is striking: the zircon $\mathrm{Hf}$ isotopes from Eoarchean sample $6 \mathrm{~B}$ plot near the upper radiogenic limit $\left({ }^{176} \mathrm{Lu} /{ }^{177} \mathrm{Hf} \sim 0.025\right)$ for meta-igneous zircons from the Jack Hills, the Acasta Gneiss and the Amitsoq gneiss on an $\varepsilon_{\mathrm{Hf}}$-time plot as identified by Kemp et al. (2010; Fig. 5), whereas Eo-Neoarchean events characterized by TTG genesis followed by K-rich granite intrusion are typical of Archean terranes worldwide. These results emphasize the global nature of early Earth processes, and the potential to gain new insight into the evolution of early continental crust through further investigation into the well-preserved Hjørnedal Eoarchean rocks.

\subsection{Regional correlations and paleogeographic considerations}

At the regional scale, our data from Hjørnedal can be used in conjunction with the growing body of data on basements gneisses from the East Greenland Caledonides to place new constraints on the extent of the East Greenland Archean domain (EGAD, Fig. 2), and the Archean-Paleoproterozoic architecture of East Greenland. The Meso-Neoarchean basement ages in the Hjørnedal region are comparable to 2824-2630 Ma TTG and granitic gneisses documented in Gletscherland farther north in the East Greenland Caledonides (Fig. 1; Thrane, 2002). The Gletscherland orthogneisses are also exposed within the Niggli Spids thrust sheet structurally beneath Krummedal sequence, and are likely correlative to the Hjørnedal rocks. Furthermore, these Archean rocks within the East Greenland Caledonides are apparently isolated from the Archean rocks of the Greenland shield by Paleoproterozoic basement gneisses exposed in the parautochthonous foreland (Higgins and
Leslie, 2004; Thrane, 2004). Taken together, the EGAD can be characterized as an isolated Meso-Neoarchean terrane that includes fragments of Eoarchean crust, is relatively undisturbed by Paleoproterozoic events, and stretches a minimum of $300 \mathrm{~km}$ along the coast of East Greenland (Fig. 2). Farther south, Meso-Neoarchean rocks are also exposed within the gneiss complexes north of the Nagssugtoquidian orogen in East Greenland (Fig. 2; Nutman et al., 2008b). These gneisses may represent a southern continuation of the EGAD, although convincing correlations of these rocks with the Archean orthogneisses of the East Greenland Caledonides are made difficult by lack of data and limited outcrop due to the Greenland ice sheet and Cenozoic volcanics which obscure the Archean-Paleoproterozoic contact relationships between the two regions.

The results of this study, when placed in context with compilations of recent regional-scale mapping projects in East Greenland (Higgins and Leslie, 2008; Higgins et al., 2004, and references therein), highlight the improved understanding of the Archean-Paleoproterozoic architecture of East Greenland which serves as new dataset that can be used to evaluate geologicallymodified paleomagnetic reconstructions of Paleoproterozoic Nuna. In order to apply the Archean-Paleoproterozoic architecture of East Greenland to paleomagnetic reconstructions of Nuna, we first assume that prior to Caledonian deformation the EGAD and its bounding Paleoproterozoic terranes originated ESE of their current location with respect to East Greenland in the Late Paleoproterozoic. Although more significant post-Paleoproterozoic displacement and an exotic origin for the EGAD cannot be ruled out, the assumption of relative proximity to the East Greenland shield in the Late Paleoproterozoic is reasonable given (1) WNW transport direction of Caledonian thrust sheets indicative of a location $<400 \mathrm{~km}$ to the ESE prior to Caledonian orogenesis (Higgins et al., 2004), (2) the lack of 940-910 Ma Sveconorwegian thermal effects in the parautochthonous foreland and in the Niggli Spids thrust sheet (Higgins et al., 2004; Leslie and Nutman, 2003; Strachan et al., 1995), suggesting that significant Early Neoproterozoic deformation in East Greenland was limited to rocks originally farther east and outboard of the EGAD, and (3) 2010-1910 Ma calc-alkaline magmatism in the East Greenland thrust sheets (Kalsbeek et al., 1993b; Thrane, 2002) located proximally to East Greenland is consistent with the N-to-S Paleoproterozoic growth of the Greenland shield (Nutman et al., 2008b). Given this assumption of proximity to the East Greenland shield in the latest Paleoproterozoic, the most recent raw paleomagnetic data places the northern edge of Baltica adjacent to East Greenland (e.g., Fig. 2; Buchan et al., 2000; Pesonen et al., 2003), and suggest several previously unrecognized potential correlations between Archean and Paleoproterozoic terranes of Baltica and East Greenland. $1830 \mathrm{Ma}$ paleomagnetic reconstructions, based on non-key paleopoles, suggest a possible correlation between the EGAD and Murmansk Archean terranes, and/or the presence of several elongate individual Archean microcontinental fragments tightly arranged between a network of Paleoproterozoic rocks (Fig. 2A) analogous to Archean-Paleoproterozoic relationships in the Torngat orogen of Labrador. Alternatively, $1265 \mathrm{Ma}$ paleomagnetic reconstructions which are based on more reliable key paleopoles and likely valid as early as $\sim 1800 \mathrm{Ma}$ when it is thought that the various Archean cratons coalesced (e.g., Buchan et al., 2000), suggest correlation of Karelia with the EGAD and the Lapland-Kola orogen with the Paleoproterozoic terranes of the East Greenland Caledonian foreland and thrust sheets (Fig. 2B). The potential correlations identified here provide geologic support for raw paleomagnetic reconstructions that place Baltica farther north along the coast of East Greenland (present-day coordinates) than typical geologically-modified paleomagnetic models for Nuna that correlate the Nagssugtoquidian and Lapland-Kola orogens (e.g., Bridgwater et al., 1990; Buchan et al., 2000; Gorbatschev 
and Bogdanova, 1993; Gower et al., 1990; Park, 1994). Although this more northerly location of Baltica within Nuna and its associated terrane correlations need to be vetted through additional field, geochemical and geochronological studies in East Greenland Archean-Paleoproterozoic rocks required for detailed comparison with other North Atlantic terranes, the recognition of mapable Archean-Paleoproterozoic terranes in East Greenland emphasizes the potential for further studies of the Precambrian architecture of East Greenland to add to our understanding of the growth and eventual demise of Paleoproterozoic Nuna.

\section{Conclusion}

This combined geochemical and geochronological study identifies a composite Eo-Meso-Neoarchean terrane in the East Greenland Caledonides. The discovery of Eoarchean rocks in East Greenland expands the database of known Archean terranes with rocks $>3.6 \mathrm{Ga}$ worldwide, and provides a new setting in which to investigate early Earth processes. In addition, this study in conjunction with recently completed mapping projects in East Greenland, define an aerially significant Archean terrane within the East Greenland Caledonides suggestive of an Archean-Paleoproterozoic geologic framework supportive of raw paleomagnetic models for the Baltica-Laurentia configuration within Paleoproterozoic Nuna.

\section{Acknowledgements}

This project was funded by NSF 0838530 awarded to Johnston. We thank Ebbe Hartz for use of his field equipment, Aka Lynge for assistance with field transportation while in Greenland, and Matthew Eastlick for assistance with zircon mineral separates. This paper has benefitted from comments by Wouter Bleeker and several anonymous reviewers on earlier versions of the manuscript.

\section{Appendix A. Supplementary data}

Supplementary data associated with this article can be found, in the online version, at http://dx.doi.org/10.1016/ j.precamres.2013.07.004.

\section{References}

Bouvier, A., Vervoort, J., Patchett, P., 2008. The Lu-Hf and Sm-Nd isotopic composition of CHUR: constraints from unequilibrated chondrites and implications for the bulk composition of terrestrial planets. Earth and Planetary Science Letters 273, 48-57.

Bridgwater, D., Austrheim, H., Hansen, B.T., Mengel, F., Pedersen, S., Winter, J., 1990. The Proterozoic Nagssugtoquidian mobile belt of southeast Greenland: a link between the eastern Canadian and Baltic shields. Geoscience Canada 17, 305-310.

Buchan, K.L., Mertanen, S., Park, R.G., Pesonen, L.J., Elming, S.-Å., Abrahamsen, N., Bylund, G., 2000. Comparing the drift of Laurentia and Baltica in the Proterozoic: the importance of key paleomagnetic poles. Tectonophysics, 167-198.

Daly, J.S., Balagansky, V.V., Timmerman, M.J., Whitehouse, M.J., 2006. The Lapland-Kola orogen: Palaeoproterozoic collision and accretion of the northern Fennoscandian lithosphere. In: Gee, D.G., Stephenson, R.A. (Eds.), European Lithosphere Dynamics. Geological Society, London, Memoirs, pp. 579-598.

Friderichsen, J.D., 1984. 10 Ø.4 Syd, Vestfjord; $1: 100,000 ; 70^{\circ} 30^{\prime} \mathrm{N}-70^{\circ} 00^{\prime} \mathrm{N} ; 30$ $42^{\prime}$ W-28 $21^{\prime}$ W. Geological Survey of Denmark and Greenland.

Garde, A.A., Hamilton, M.A., Chadwick, B., Grocott, J., McCaffrey, K.J.W., 2002. The Ketilidian orogen of South Greenland: geochronology, tectonics, magmatism, and fore-arc accretion during the Palaeoproterozoic oblique convergence. Canadian Journal of Earth Sciences 39, 765-793.

Gilotti, J.A., McClelland, W.C., 2011. Geochemical and geochronological evidence that the North-East Greenland ultrahigh-pressure terrane is laurentian crust. The Journal of Geology 119, 439-456.

Gorbatschev, R., Bogdanova, S., 1993. Frontiers in the Baltic shield. Precambrian Research 64, 3-21.

Gower, C.F., Ryan, A.B., Rivers, T., 1990. Mid-Proterozoic Laurentia-Baltica: an overview of its geological evolution and a summary of the contributions made by this volume. In: Gower, C.F., Rivers, T., Ryan, B. (Eds.), Mid-Proterozoic Laurentia-Baltica. Geological Association of Canada, Special Paper 38, pp. 1-20.
Hansen, B., Steiger, R., Higgins, A., 1981. Isotopic evidence for a Precambrian metamorphic event within the Charcot Land window, East Greenland Caledonian fold belt. Bulletin Geological Society of Denmark 29, 151-160.

Henriksen, N., 1985. 70 Ø.3 Syd, Gåsefjord; 1:100,000; 70 30' N-70 00' N; $28^{\circ} 21$ W-26 $00^{\prime}$ W. Geological Survey of Denmark and Greenland.

Higgins, A., Leslie, A., 2004. The Eleonore Sø and Målebjerg foreland windows, East Greenland Caledonides, and the demise of the stockwerke concept. Geological Survey of Denmark and Greeland Bullentin 6, 77-93.

Higgins, A., Leslie, A., 2008. Architecture and evolution of the East Greenladn Caledonides-an introduction. In: The Greenland Caledonides: Evolution of the Northeast Margin of Laurentia. Geological Society of America Memoir, pp. 29-53.

Higgins, A.K., Elvevold, S., Escher, J.C., Frederiksen, K.S., Gilotti, J.A., Henriksen, N., Jepsen, H.F., Jones, K.A., Kalsbeek, F., Kinny, P.D., Leslie, A.G., Smith, M.P., Thrane, K., Watt, G.R., 2004. The foreland-propagating thrust architecture of the East Greenland Caledonides, $72-75^{\circ} \mathrm{N}$. Journal of the Geological Society of London 161, 1009-1026.

Hoffman, P.F., 1997. Tectonic genealogy of North America. In: Van der Pluijm, B.A., Marshak, S. (Eds.), Earth Structure: An Introduction to Structural Geology and Tectonics. McGraw-Hill, New York, NY, pp. 459-464.

Johnston, S.M., Kylander-Clark, A., Salimbene, J., 2010. Timing of metamorphism in the Niggli Spids thrust sheet, Gaaseland, East Greenland Caledonides. Eos, Transactions American Geophysical Union 91, T51A-2018.

Kalsbeek, F., Austrheim, H., Bridgwater, D., Hansen, B.T., Pedersen, S., Taylor, P.N., 1993a. Geochronology of Archaean and Proterozoic events in the Ammassalik area, South-East Greenland, and comparisons with the Lewisian of Scotland and the Nagssugtoquidian of West Greenland. Precambrian Research 62, 239-270.

Kalsbeek, F., Nutman, A.P., Taylor, P.N., 1993b. Palaeoproterozoic basement province in the Caledonian fold belt of North-East Greenland. Precambrian Research 63, 163-178.

Karlstrom, K.E., Åhäll, K., Harlan, S.S., Williams, M.L., McLelland, J., Geissman, J.W., 2001. Long-lived $(1.8-1.0 \mathrm{Ga})$ convergent orogen in southern Laurentia, its extensions to Australia and Baltica, and implications for refining Rodinia. Precambrian Research 111, 5-30.

Kemp, A., Wilde, S., Hawkesworth, C., Coath, C., Nemchin, A., Pidgeon, R., Vervoort, J., DuFrane, S., 2010. Hadean crustal evolution revisited: New constraints from $\mathrm{Pb}-\mathrm{Hf}$ isotope systematics of the Jack Hills zircons. Earth and Planetary Science Letters 296, 45-56.

Kylander-Clark, A.R.C., Hacker, B., Cottle, J., 2013. Laser-ablation split-stream ICP petrochronology. Chemical Geology 345, 99-112.

Leslie, A.G., Higgins, A.K., 2008. Foreland-propagating Caledonian thrust systems in East Greenland. In: Higgins, A.K., Gilotti, J.A., Smith, M.P. (Eds.), The Greenland Caledonides: Evolution of the Northeast Margin of Laurentia, vol. 202. Geological Society of America Memoir, pp. 169-199, http://dx.doi.org/10.1130/2008.1202(07).

Leslie, A.G., Nutman, A.P., 2003. Evidence for Neoproterozoic orogenesis and early high temperature Scandian deformation events in the southern East Greenland Caledonides. Geological Magazine 3, 309-333.

Martin, H., 1994. The Archean grey gneisses and the genesis of the continental crust. In: Condie, K.C. (Ed.), The Archean Crustal Evolution, Developments in Precambrian Geology. Elsevier, Amsterdam, Netherlands, pp. 205-259.

Mojzsis, S.J., Harrison, T.M., 2002. Establishment of a 3.83-Ga magmatic age for the Akilia tonalite (southern West Greenland). Earth and Planetary Science Letters, 202.

Nironen, M., 1997. The Svecofennian Orogen: a tectonic model. Precambrian Research 86, 21-44.

Nutman, A., McGregor, V., Friend, C., Bennett, V., Kinny, P., 1996. The Itsaq Gneiss Complex of southern West Greenland; the world's most extensive record of early crustal evolution (3900-3600 Ma). Precambrian Research 78, 1-39.

Nutman, A.P., Dawes, P.R., Kalsbeek, F., Hamilton, M.A., 2008a. Palaeoproterozoic and Archaean gneiss complexes in northern Greenland: Palaeoproterozoic terrane assembly in the High Arctic. Precambrian Research 161, 419-451.

Nutman, A.P., Kalsbeek, F., Friend, C.R.L., 2008b. The Nagssugtoquidian orogen in south-east Greenland: evidence for Paleoproterozoic collision and plate assembly. American Journal of Science 308, 529-572. http://dx.doi.org/10.2475/04.2008.06.

Park, R., 1994. Early Proterozoic tectonic overview of the northern British Isles and neighbouring terrains in Laurentia and Baltica. Precambrian Research 68, 65-79.

Patchett, P.J., Bylund, G., Upton, B.G.J., 1978. Palaeomagnetism and the Grenville orogeny: new Rb-Sr ages from dolerites in Canada and Greenland. Earth and Planetary Science Letters 40, 349-364.

Pedersen, S.A.S., Craig, L.E., Upton, B.G.J., Ramo, T.O., Jepsen, H.F., Kalsbeek, F., 2002. Palaeoproterozoic (1740 Ma) rift-related volcanism in the Hekla Sund region, eastern North Greenland: field occurrence, geochemistry and tectonic setting. Precambrian Research 114, 327-346.

Pesonen, L., Elming, S.-A., Mertanen, S., Pisarevsky, S., D’Agrella-Filho, M.S., Meert, J.G., Schmidt, P.W., Abrahamsen, N., Bylund, G., 2003. Palaeomagnetic configuration of continents during the Proterozoic. Tectonophysics 375, 289-324.

Poorter, R.P.E., 1976. Palaeomagnetism of the Svecofennian Loftahammar gabbro and some Jotnian dolerites in the Swedish part of the Baltic Shield. Physics of the Earth and Planetary Interiors, 51-64.

Rex, D.C., Gledhill, A.R., 1974. Reconnaissance geochronology of the infracrustal rocks of Flyverfjord, Scoresby Sund, East Greenland. Bulletin Geological Society of Denmark, 23.

Scherer, E.E., Münker, C., Mezger, K., 2001. Calibration of the lutetium-hafnuim clock. Science 295, 683-686. 
Slabunov, A.I., Lobach-Zhuchenko, S.B., Bibikova, E.V., Sorjonen-Ward, P., Balagansky, V.V., Volodichev, O.I., Shchipansky, A.A., Svetov, S.A., Chekulaev, V.P., Arestova, N.A., Stepanov, V.S., 2006. The Archaean nucleus of the Fennoscandian (Baltic) Shield. In: Gee, D.G., Stephenson, R.A. (Eds.), European Lithosphere Dynamics. Geological Society, London, Memoirs, pp. 627-644.

Slama, J., Walderhaug, O., Fonneland, H., Kosler, J., Pedersen, R., 2011. Provenance of Neoproterozoic to upper Cretaceous sedimentary rocks, eastern Greenland: implications for recognizing the sources of sediments in the Norwegian Sea. Sedimentary Geology 238, 254-267.

Steiger, R., Hansen, B., Schuler, C., Bär, M., Henriksen, N., 1979. Polyorogenic nature of the southern Caledonian fold belt in East Greenland: an isotopic age study. Journal of Geology 87, 475-495

St-Onge, M.R., Van Gool, J.A.M., Garde, A.A., Scott, D.J., 2009. Correlation of Archaean and Palaeoproterozoic units between northeastern Canada adn western Greenland: constraining the pre-collisional upper plate accretionary history of the Trans-Hudson orogen. In: Cawood, P.A., Kröner, A. (Eds.), Earth Accretionary Systems in Space and Time. The Geological Society, London, Special Publications, pp. 193-235.
Strachan, R.A. Nutman, A.P., Friderichsen, J.D., 1995 . SHRIMP U-Pb geochronology and metamorphic history of the Smallefjord sequence, NE Greenland Caledonides. Journal of the Geological Society of London 152, 779-784.

Thrane, K., 2002. Relationships between Archaean and Paleoproterozoic crystalline basement complexes in the southern part of the East Greenland Caledonides: an ion microprobe study. Precambrian Research 113, 19-42.

Thrane, K., 2004. Palaeoproterozoic age of a basement gneiss complex in the Charcot Land tectonic window, East Greenland Caledonides. Geological Survey of Denmark and Greenland Bulletin 6, 57-66.

Watson, E., Harrison, T., 1983. Zircon saturation revisited: temperature and composition effects in a variety of crustal magma types. Earth and Planetary Science Letters 64, 295-304.

Weis, D., Demaiffe, D., Souchez, R., Gow, A.J., Meese, D.A., 1997. Ice sheet development in Central Greenland: implications from the $\mathrm{Nd}, \mathrm{Sr}$, and $\mathrm{Pb}$ isotopic compositions of the basal material. Earth and Planetary Science Letters 150 $161-169$ 